\title{
Can integrated methods stop starthistle?
}

Y ellow starthistle may be California's "thorniest" problem, currently infesting up to 22 million acres or about $22 \%$ of the state, according to estimates by the California Department of Food and Agriculture (CDFA).

Once a minor annoyance, it is now the state's most widely distributed weed. It quickly dominates any area it infests, making ranchland unusable, hiking trails impassable, and wildlands uninhabitable for a wide range of native plants and animals. It can be fatal to horses if ingested in high doses.

But now, thanks to years of scientific research and a recent lucky accident, scientists may be turning the corner in their quest for control of this noxious pest.

In this issue of California Agriculture, UC, CDFA and U.S. Department of Agriculture scientists report on a newly registered growth control herbicide ( $\mathrm{p} .12$ ), mowing as a cultural control (p. 17) and biological control agents (p. 8).

Biological control efforts were recently boosted by the accidental introduction of the false peacock fly (p. 8). Although six other biocontrol agents had previously been released, this seventh, uninvited guest was the first to sharply reduce late-season starthistle seed.

Starthistle is a prodigious seed-producer, and remarkably, $95 \%$ of its seeds germinate. What's more, its flowering and germination continue from May through September.

"Unlike the other biocontrols established here, false peacock fly has multiple generations per year, and its attack is sustained throughout yellow starthistle's lengthy flowering period," says Joe Balciunas, USDA research entomologist and Yellow Starthistle Biocontrol Project Leader. "None of the other approved and established agents attack these late-blooming flowers."

Scientists have found that false peacock fly has attacked from $36 \%$ to $50 \%$ of starthistle seed heads at sites where it has recently established; seed heads containing the fly's larva have $78 \%$ less seed. By contrast the true peacock fly which is physically almost identical to its "false" counterpart - has never been observed to attack more than $5 \%$ of starthistle seed heads.

While the false peacock fly has managed to establish itself at many locations throughout the state, its use cannot yet be recommended because it has not been approved for release. Its host range is now being tested; early results suggest it does not adversely affect commercial crops.

Also in this issue, UC Cooperative Extension weed scientist Joseph DiTomaso and colleagues report on trials using a newly registered growth-control herbicide clopyralid (tradename Transline). They have developed guidelines for its use, as well as for the most effective use of a cultural control, mowing.

Due to environmental concerns, few herbicides are registered for use on rangelands and wildlands. Of those that are, few are active in the soil against seeds that may germinate for months.

The new growth regulator clopyralid, however, controls starthistle by arresting its development at the growing points both on the plant and on the seedlings that germinate in the soil. It provides better than $95 \%$ control with residual activity throughout the starthistle season.

Clopyralid is selective, affecting only a few plants. (These plants include not only noxious thistles but some legumes such as clover, alfalfa, and vetch.) Because of clopyralid's relative safety, it can also be used in combination with livestock grazing.

DiTomaso, in collaboration with CDFA entomologist Michael Pitcairn, is examining joint use of biological control agents and the new growth regulator herbicide. DiTomaso and UC colleagues are also studying combinations of burning, reseeding, herbicide use and biocontrol.

"In addition to managing yellow starthistle, our goal is to develop a healthy and sustainable system," says DiTomaso. "No single control method is enough to do this, but a combination of methods may.

"The specific plan you may develop for any particular infested area would depend on your goals. For instance, if you want to restore perennial grass forage to a thistle-infested grazing area, you could use clopyralid, or clopyralid plus glyphosate, in the first year, then reseed with a desirable perennial grass, and use clopyralid a second year. In subsequent years, the combination of competitive perennial grass and the biocontrol agents would be expected to maintain low levels of starthistle." -Editor

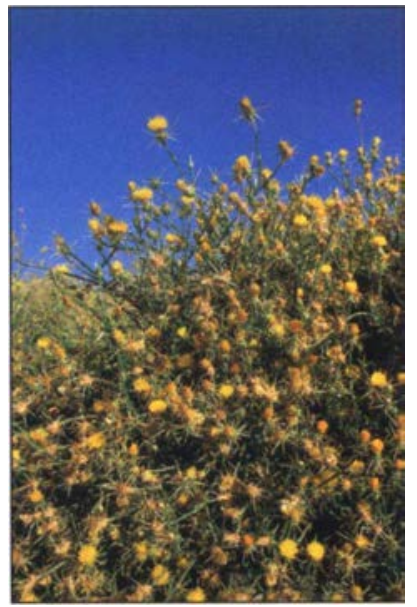

Starthistle, which first invaded California during the Gold Rush, covered approximately 1.2 million acres by the 1960s. Starthistle now blankets an estimated 22 million acres of California landscape. 